\title{
Implementasi Manajemen Kurikulum Dalam Mengembangkan Kompetensi Siswa Pada Mata Pelajaran Biologi
}

\author{
Rodi Purwanto ${ }^{1}$, Nur Ahyani ${ }^{2}$, Dessy Wardiah ${ }^{3}$ \\ 1,2,3 Pascasarjana Universitas PGRI Palembang \\ 1Email: rodibunglai@gmail.com \\ 2Email: dessywardiah77@univpgri-palembang.ac.id \\ ${ }^{3}$ Email: ${ }^{1}$ Email: nurahyani63@gmail.com
}

\begin{tabular}{l}
\hline \multicolumn{1}{c}{ Jounal info } \\
\hline Jurnal Pendidikan Glasser \\
p-ISSN $: 2579-5082$ \\
e-ISSN : 2598-2818 \\
DOI : $10.32529 /$ glasser.v5i1.850 \\
Volume $: 5$ \\
Nomor : 1 \\
Month : 2021 \\
Issue : April
\end{tabular}

\section{A. PENDAHULUAN}

Pendidikan merupakan salah satu aspek penting dalam pembangunan suatu bangsa. Adanya pendidikan merupakan suatu kewajiban dan pengelolaan pendidikan yang berkualitas adalah suatu keharusan jika bangsa tersebut ingin maju dan dapat bersaing dengan bangsa-bangsa lainnya. Oleh karena itu, pendidikan harus dilaksanakan dan

\begin{abstract}
.
Sekolah merupakan ujung tombak pelaksanaan kurikulum yang diwujudkan melalui proses belajar mengajar untuk mencapai tujuan pendidikan nasional. Penelitian ini bertujuan untuk mengetahui dan mendeskripsikan Implementasi Manajemen Kurikulum Dalam Mengembangkan Kompetensi Siswa pada Mata Pelajaran Biologi (Studi Kasus di SMA Negeri 8 Ogan Komering Ulu). Metode penelitian menggunakan metode deskriftif kualitatif. Teknik pengumpulan data menggunakan wawancara, observasi, dan dokumentasi. Wawancara dilakukan dengan kepala sekolah, wakil kepala sekolah bidang kurikulum, guru Biologi dan siswa. Hasil penelitian menyatakan bahwa implementasi manajemen kurikulum dalam mengembangkan kompetensi siswa pada mata pelajaran biologi, dengan tahap: 1) perencanaan yang melibatkan tim pengembang kurikulum yang terdiri dari kepala sekolah, wakil-wakil kepala sekolah, guru, komite sekolah dan tenaga ahli dari dewan pakar. 2) Pengorganisasian dan pengkoordinasian kurikuklum; 3) pelaksanaan kurikulum dan 4) Evaluasi kurikulum, yang dilakukan dengan memeriksa dokumen kurikulum, wawancara, dan supervisi kelas oleh Kepala sekolah dibantu oleh Wakil Kepala Sekolah Bidang Kurikulum dengan panduan instrumen penelitian.
\end{abstract}

Keywords: Manajemen Kurikulum, Kompetensi Siswa, Biologi

dikelola dengan baik untuk menghasilkan lulusan-lulusan yang unggul dan yang paling penting memiliki akhlak mulia. Apalagi dengan masuknya di era Revolusi Industri 4.0, pada era tersebut menuntut Sumber Daya Manusia (SDM) yang berkualitas baik dari segi kompetensi maupun dari segi sikap. Konsistensi dan komitmen untuk mewujudkan pendidikan yang berkualitas 
menjadi salah satu kunci utama agar pendidikan di suatu negara menjadi tumbuh dan berkembang maju menghadapi tantangan zaman di depan.

Keyakinan masyarakat tentang pendidikan merupakan salah satu sarana yang paling efektif dalam peningkatan kualitas sumber daya manusia yang mampu mengantisipasi berbagai tantangan masa depan dan keyakinan tersebut kemudian bermetamorfosis menjadi sebuah harapan. Dalam konteks ini, sekolah sebagai bagian dari lembaga pendidikan, menerapkan konsep kurikulum yang tentunya dilandasi oleh semangat untuk menjawab keyakinan dan harapan masyarakat tersebut. Dalam perkembangannya, kurikulum sebagai program belajar bagi peserta didik disusun secara sistematis dan logis dalam mencapai tujuan pendidikan. Kurikulum sebagai program sebagai niat, rencana, dan harapan. Oleh karena itu, kurikulum dapat dikatakan sebagai hasil belajar yang diharapkan (intended learning outcomes) (Sukirman \& Nugraha, 2016).

Kurikulum yang dipraktikkan dalam dunia pendidikan selama ini masih banyak yang berorientasi pada pencapaian kemajuan akademik. Hal ini tidak sejalan dengan tujuan pendidikan nasional yang menyatakan bahwa spektrum tujuan yang harus dicapai oleh pendidikan lebih luas dari sekedar aspek akademik (Lazwardi, 2017). Dalam porsi yang besar, tujuan pendidikan meliputi pembentukan sikap, nilai, dan keterampilan yang justru dewasa ini masih terabaikan yang pada gilirannya akan menghambat tercapainya pembentukan kepribadian manusia seutuhnya. Implementasi kurikulum 2013 menuntut guru untuk secara profesional merancang pembelajaran efektif dan bermakna, mengorganisasikan pembelajaran, memilih pendekatan yang tepat, menentukan prosedur pembelajaran dan pembentukan kompetensi secara efektif, serta menetapkan kriteria keberhasilan (Ikhsan \& Anisykurlillah, 2010).

Perubahan elemen standar isi pada Kurikulum 2013 membuat guru yang selama ini menggunakan evaluasi tradisional harus mengubah evaluasinya yaitu menjadi evaluasi autentik berdasarkan tuntutan kurikulum. Evaluasi autentik pada kurikulum 2013 yaitu dari yang berfokus pada pengetahuan melalui evaluasi output menjadi berbasis kemampuan melalui evaluasi proses, portofolio dan evaluasi output secara utuh dan menyeluruh (Fadillah, Mardianto, \& Nasultion, 2018). Dalam implementasi Kurikulum 2013, prestasi belajar dapat diintegrasikan dalam seluruh pembelajaran pada setiap bidang studi yang terdapat dalam kurikulum. Materi pembelajaran yang berkaitan dengan norma atau nilai-nilai pada setiap bidang studi perlu dikembangkan, dieksplisitkan, dihubungkan dengan konteks kehidupan sehari-hari. Dengan demikian, pendidikan nilai dan prestasi belajar tidak hanya dilakukan pada tataran kognitif, tetapi menyentuh internalisasi dan pengalaman nyata dalam kehidupan sehari-hari. Setelah menjalani proses pembelajaran secara keseluruhan, 
lulusan diharapkan memiliki sikap, pengetahuan, dan keterampilan.

Sekolah merupakan ujung tombak pelaksanaan kurikulum yang diwujudkan melalui proses belajar mengajar untuk mencapai tujuan pendidikan nasional, institusional, kurikuler dan instruksional. Agar proses belajar-mengajar dapat dilaksanakan secara efektif dan efisien, serta mencapai hasil yang diharapkan, diperlukan kegiatan manajemen program dan pengajaran.

Manajer sekolah diharapkan dapat membimbing dan mengarahkan pengembangan kurikulum dan program pengajaran pengawasan dalam pelaksanaannya.

Manajemen kurikulum bukan hanya dibatasi dalam ruang kelas, tetapi menyangkut pula di dalam kegiatan pengelolaan di luar kelas, bahkan di luar sekolah (Nasbi, 2017). Sebuah organisasi yang akan mengatur dan mengelola kegiatan yang akan dilaksanakan oleh guru dan murid sebagai pelaksana kegiatan kurikulum di sekolah, selain itu manajemen kurikulum dirancang agar perencanaan, pelaksanaan dan evaluasi kurikulum berjalan lebih efektif, efisien dan optimal dalam memberdayakan sumber belajar, pengalaman maupun komponen kurikulum. Manajemen kurikulum memiliki cakupan yang luas dalam pelaksanaannya karena bagaimana pun kegiatan ini bukan hanya akan mengatur kegiatan pembelajaran agar mencapai tujuan kurikulum saja akan tetapi di luar itu pula manajemen kurikulum dapat bekerja. Seperti halnya mengarahkan visi, misi yang telah ditetapkan dalam kurikulum juga meningkatkan efektivitas kinerja guru maupun meningkatkan efektivitas dan efesiensi proses belajar mengajar.

Pada pelaksanaanya, manajemen kurikulum pada tiap dinas atau kementerian hingga pada tingkat sekolah memiliki karakteristik yang berbeda-beda sehingga menghasilkan standar dan kualitas yang berbeda pula dalam implementasi manajemen kurikulum K13 antara satu sekolah dengan sekolah lain pasti berbeda dalam proses pengelolaannya. Di lingkungan sekolah Implementasi manajemen kurikulum K13 memerlukan persiapan yang baik dalam tahapan awal implementasinya baik itu dari pemahaman guru tentang K13 sampai cara penerapan K13 dalam pembelajaran, dan juga perbedaan sekolah dalam mempersiapkan, melaksanakan hingga mengevaluasi kegiatan atau program sekolah yang akan dilaksanakan dalam satu tahun pelajaran.

Adanya manajemen kurikulum akan membantu sekolah dalam mengelola kurikulum, dimulai dari perencanaan, pengorganisasian, pelaksanaan, dan evaluasi kurikulum sehingga dapat mencapai tujuan pembelajaran dan pendidikan dengan efektif. Masalah yang dapat muncul dalam implementasi manajemen kurikulum adalah inersia. Inersia dapat terjadi jika manajemen atau pengelolaan kurikulum sekolah tidak dilakukan dengan baik dan benar, baik 
berkenaan dengan distribusi dan ketersediaan dokumen kurikulum di sekolah, sosialisasi ide dan dokumen, pemberian bantuan profesional kepada kepala sekolah, perencanaan sekolah dalam implementasi, kualifikasi dan beban kerja guru, suasana dan fasilitas kerja guru, pemantauan proses, dan tindak lanjut program. Jika inersia terjadi dalam manajemen kurikulum di sekolah, maka implementasi kurikulum tidak akan dapat berjalan sesuai dengan apa yang diharapkan dan hal ini akan berimbas kepada kualitas pendidikan yang semakin menurun.

Biologi merupakan salah satu cabang ilmu yang mengkaji segala sesuatu tentang kehidupan. Biologi adalah salah satu ilmu pengetahuan alam (IPA) yang berkaitan erat dengan cara mencari tahu dan memahami alam semesta secara sitematis, sehingga Biologi bukan hanya merupakan penguasaan kumpulan pengetahuan yang berupa faktafakta, konsep-konsep dan prinsip-prinsip saja tetapi juga merupakan suatu proses menemukan (Herdani, Sartono, \& Evriyani, 2015). Pembelajaran biologi berhubungan dengan alam nyata dan berkaitan dengan proses-proses kehidupan. Agar siswa dapat memahaminya, maka metode dan pendekatan yang digunakan dalam proses pembelajaran biologi harus disesuaikan dengan karakteristik objek dan subjek belajarnya. Pembelajaran biologi diharapkan mampu menjawab tentang fenomena alam dan makhluk hidup yang ada didalamnya dan mampu menunjang perkembangan ilmu pengetahuan dan teknologi yang berguna bagi kemaslahatan masyarakat yang dapat dilihat dari hasil kreativitas siswa. Seseorang dikatakan kreatif apabila terjadi perubahan yang menghasilkan sesuatu yang baru.

Pada dasarnya dalam mengembangkan Ilmu Pengetahuan dan teknologi (IPTEK), tentunya membutuhkan fasilitas serta jam pelajaran yang cukup (Pebriantika, 2018). Namun terkait dengan pembelajaran yang dilaksanakan di SMA Negeri 8 OKU dengan proses pembelajaran yang terbatas, tentunya masih kurang produktif untuk meningkatkan kompetensi siswa SMA Negeri 8 OKU di bidang biologi.

\section{B. METODE PENELITIAN}

Penelitian ini merupakan penelitian deskriptif kualitatif. Metode deskriptif kualitatif digunakan untuk mendapatkan data yang mendalam dan menjabarkannya, suatu data yang mengandung makna. Makna adalah data yang sebenarnya, data yang pasti yang merupakan suatu nilai dibalik data yang tampak. Oleh karena itu dalam penelitian kualitatif tidak menekankan generalisasi, tetapi lebih menekankan pada makna. (Sugiyono, 2019:36).

Subyek penelitian adalah kepala sekolah dan guru Biologi SMA Negeri 8 Ogan Komering Ulu. Teknik pengumpulan data yang digunakan dalam penelitian ini adalah teknik observasi, teknik wawancara, dan dokumentasi. Analisis data dilakukan melalui tahap reduksi (data reduction), penyajian data (data display), dan penarikan kesimpulan (verification). Pemeriksaan 
keabsahan data menggunakan trianggulasi yang merupakan teknik pemeriksaan keabsahan data dengan memanfaatkan sesuatu yang lain diluar data itu untuk keperluan pengecekan data atau sebagai pembanding terhadap data itu.

\section{HASIL DAN PEMBAHASAN}

\section{Perencanaan Kurikulum}

Mencermati temuan pertama, perencanaan kurikulum sangat tergantung pada pengembangan kurikulum dan tujuan kurikulum yang akan menjadi penghubung teori-teori pendidikan yang digunakan. Perencanaan tidak bisa direncanakan oleh pimpinan dan diputuskan oleh beberapa orang saja. Sesuai dengan hasil observasi dan wawancara, bahwa perencanaan kurikulum disusun dengan melibatkan tim pengembang kurikulum. Personel yang terlibat dalam tim pengembang kurikulum adalah kepala sekolah, para wakil kepala sekolah, ketua komite, guru, dan tenaga ahli dari dewan pakar.

Fokus perencanaan kurikulum pada mata pelajaran biologi dimulai dengan menganalisis konteks, kebutuhan dan standar nasional pendidikan. Selain itu, SMA Negeri 8 OKU sudah merencanakan akan mengadakan kegiatan belajar tambahan khusus pada mata pelajaran biologi dalam mengembangkan kompetensi siswa. Hal ini menunjukkan bahwa perencanaan dilakukan secara terus menerus dan adanya sikap untuk menindaklanjuti kegiatan yang sudah berjalan. Kondisi yang terjadi di SMA Negeri 8 OKU dalam perencanaan kurikulum pada mata pelajaran biologi melibatkan semua komponen yang terkait dengan perencanaan kurikulum.

\section{Pengorganisasian Kurikulum}

Mencermati temuan kedua, Kepala SMA Negeri 8 OKU membentuk Wakil Kepala Sekolah Bidang Kurikulum dan Wakil Kepala Sekolah Bidang MGMP dalam hal pengorganisasian kurikulum. Tugas kedua wakil kepala sekolah ini adalah untuk membantu kepala sekolah dalam mengorganisasikan kurikulum. Namun, dalam praktiknya terdapat komponen-komponen pengorganisasian kurikulum yang belum terlaksana secara optimal sesuai dengan profil yang sudah direncanakan(Kurniawan \& Noviana, 2017).

Pelaksanaan fungsi pengorganisasian kurikulum dalam mengembangkan kompetensi siswa pada mata pelajaran biologi di SMA Negeri 8 OKU masih belum sepenuhnya berjalan. Terdapat wewenang yang belum terlaksana sepenuhnya dalam pelaksanaan program motivasi untuk siswa pada mata pelajaran biologi.

\section{Pelaksanaan Kurikulum}

Mencermati temuan ketiga, peranan Kepala SMA Negeri 8 OKU melakukan supervisi untuk membantu guru menemukan dan mengatasi kesulitan yang dihadapi. Selain itu juga kepala sekolah selalu memberi arahan kepada bawahan tentang pelaksanaan kurikulum pada mata pelajaran biologi dalam 
mengembangkan kompetensi. Pada sisi lain, guru menjalankan fungsi pelaksanaan kurikulum pada mata pelajaran biologi dengan cara melakukan kegiatan pembelajaran dengan model dan prinsip pembelajaran yang sesuai dengan kurikulum yang berlaku. Pemonitoran terhadap disiplin guru dan administrasi guru juga dilakukan oleh Ketua Komite SMA Negeri 8 OKU melalui wujud penggunaan dana komite untuk program-program yang direncanakan oleh kepala sekolah. Hal ini bermakna bahwa terjalin pola hubungan yang saling mendukung antara kepala sekolah dengan komite sekolah terhadap program yang akan dilakukan secara khusus.

Akan tetapi, pada implemntasi manajemen kurikulum dalam mengembangkan kompetensi pada mata pelajaran biologi terdapatnya hambatan yaitu belum tercapainya kehadiran seratus persen dari tenaga pengajar bimbingan belajar yang didatangkan dari selain tenaga pengajar SMA Negeri 8 OKU. Keadaan ini menunjukkan belum adanya tanggung jawab yang tinggi di kalangan tenaga pengajar.

Selain itu, ditinjau dari pelaksanaan kurikulum, penulis memperoleh data dari silabus dan rencana perangkat pembelajaran bahwa tidak terdapat pengembangan perangkat pembelajaran antara mata pelajaran biologi dan mata pelajaran lainnya. Pengembangan yang dimaksud meliputi pengembangan kompetensi dasar, indikator, materi ajar, dan evaluasi. Dengan demikian, secara formal dokumen 2 kurikulum biologi adalah sama dengan kurikulum mata pelajaran lainnya di SMA Negeri 8 OKU.

Adapun perbedaan antara program mata pelajaran biologi dan program mata pelajaran lainnya terletak pada penambahan jam sehabis pulang sekolah untuk mengembangkan kompetensi siswa pada mata pelajaran biologi. Siswa mendapat tambahan pembelajaran untuk mata pelajaran Biologi. Rincian perangkat pembelajaran tambahan ini, berupa pengembangan kompetensi dasar, indikator, materi ajar, dan evaluasi tidak termuat dalam dokumen 2 kurikulum.

Dengan demikian, fungsi pelaksanaan kurikulum pada mata pelajaran biologi dalam mengembangkan kompetensi di SMA Negeri 8 OKU belum berjalan secara optimal sebagaimana yang direncanakan sesuai dengan profil sekolah yang sudah direncanakan. Untuk itu, diperlukan supervisi yang jelas dan rinci oleh kepala sekolah terhadap kinerja tenaga pengajar pada mata pelajaran biologi di SMA Negeri 8 OKU.

\section{Evaluasi Kurikulum}

Mencermati temuan keempat, evaluasi kurikulum dalam mengembangkan kompetensi pada mata pelajaran biologi dilakukan oleh guru, Wakil Kepala Sekolah Bidang Kurikulum dengan Wakil Kepala Sekolah Bidang MGMP, dan Kepala SMA Negeri 8 OKU. Fokus pertama pengevaluasian kurikulum adalah pencapaian siswa terhadap kriteria ketuntasan minimal (KKM) yang telah ditetapkan. Selanjutnya fokus kedua adalah supervisi dan evaluasi terhadap pelaksanaan kurikulum oleh guru. 
Jadwal pelaksanaan evaluasi pada setiap bulan, setiap tiga bulan, setiap semester, dan setiap akhir tahun ajaran. Wakil Kepala Sekolah melakukan pengumpulan data tentang evaluasi kurikulum dan kemudian data tersebut disampaikan pada Tim Pengembang Kurikulum sebagai bahan pertimbangan evaluasi dan melakukan tindak lanjut.

Selain itu, Ketua Komite SMA Negeri 8 OKU berperan membantu Kepala SMA Negeri 8 OKU mengevaluasi pelaksanaan pembelajaran dan respon masyarakat terhadap penyelenggaraan program melalui wujud penggunaan dana komite. Dalam pelaksanaan supervisi, kepala sekolah selalu mempersiapkan dokumen yang lengkap sebelum melakukan evaluasi. Dokumen tersebut berupa instrumen penilaian secara tertulis.

Kepala sekolah berperan dalam pengendalian sistem evaluasi agar evaluasi dapat dilaksanakan sesuai dengan tujuan yang telah ditetapkan. Kepala sekolah bekerja sama dengan guru untuk melakukan evaluasi dengan objektif agar hasil evaluasi menunjukkan hasil belajar siswa yang sesungguhnya (Muhirah, 2017). Dengan demikian prestasi siwa yang diraih merupakan kerja keras siswa dalam mengikuti proses pembelajaran. Evaluasi yang dilaksanakan dengan penuh tanggung jawab dan objektif dapat mengukur kemampuan siswa yang selanjutnya berdampak pada peningkatan mutu yang berkelanjutan.
Pelaksanaan fungsi evaluasi kurikulum dalam mengembangkan kompetensi pada mata pelajaran biologi sudah berjalan dengan sebagaimana mestinya. Evaluasi kurikulum pada mata pelajaran biologi melibatkan guru, para wakil kepala sekolah, komite sekolah, dan kepala sekolah sebagai pengendali evaluasi.

\section{PENUTUP}

Berdasarkan deskripsi data dan analisis yang telah dipaparkan maka dapat ditarik kesimpulan bahwa Implementasi Manajemen Kurikulum Dalam Mengembangkan Kompetensi Siswa pada Mata Pelajaran Biologi (Studi Kasus di SMA Negeri 8 Ogan Komering Ulu), dimulai dari tahap: a) Perencanaan kurikulum disusun dengan melibatkan tim pengembang kurikulum yang terdiri dari kepala sekolah, wakil kepala sekolah, guru, komite sekolah dan tenaga ahli dari dewan pakar SMA Negeri 8 OKU; b) Pengorganisasian dan pengkoordinasian kurikulum dengan melakukan pertemuan MGMP secara formal pada setiap bulan, dan melakukan penjadwalan kegiatan penyegaran guru dengan mengikuti pendidikan dan pelatihan guru baik di dalam maupun di luar provinsi; c) Pelaksanaan kurikulum dilakukan dengan kegiatan pengawasan terhadap pelaksanaan kurikulum yang dilakukan oleh kepala sekolah. Selain itu, kepala sekolah memberi wewenang kepada wakil kepala sekolah maupun guru untuk melakukan rapat kecil (breefing) pada setiap pagi sebagai guna 
membicarakan kemajuan ataupun kekurangan yang ada; d) Evaluasi kurikulum pada mata pelajaran biologi, dilakukan oleh Kepala sekolah dibantu oleh Wakil Kepala Sekolah Bidang Kurikulum. Evaluasi dilakukan dengan memeriksa dokumen kurikulum, wawancara, dan supervisi kelas oleh Kepala sekolah dibantu oleh Wakil Kepala Sekolah Bidang Kurikulum dengan panduan instrumen penelitian

\section{E. REFERENSI}

Fadillah, Mardianto, \& Nasultion, W. (2018). Implementasi Manajemen Kurikulum dDlam Meningkatkan Kualitas Pembelajaran di SMP Wiraswasta Batang Kuis Kabupaten Deli Serdang. Jurnal At-Tazakki, 2(1).

Herdani, T., Sartono, N., \& Evriyani, D. (2015). Pengembangan Permainan Monopoli Termodifikasi Sebagai Media Pembelajaran pada Materi Sistem Hormon (Penelitian dan Pengembangan di SMAN 1 Jakarta). Biosfer, 8(1).

Ikhsan, S., \& Anisykurlillah, I. (2010). Penerapan Manajemen Berbasis Sekolah SMK Negeri Dan SMK Swasta SeKarasidenan Semarang. Jurnal Pendidikan Ekonomi Dinamika Pendidikan, V(1), 1-19.

Kurniawan, O., \& Noviana, E. (2017).
Penerapan Kurikulum 2013 Dalam Meningkatkan Keterampilan, Sikap, dan Pengetahuan. Jurnal Primary Program Studi Pendidikan Guru Sekolah Dasar Fakultas Keguruan Dan Ilmu Pendidikan Universitas Riau, 6(2),

Lazwardi, D. (2017). Manajemen Kurikulum Sebagai Pengembangan Tujuan Pendidikan. Al-Idarah: Jurnal Kependidikan Islam V, 7(1), 99-112.

Muhirah. (2017). Evaluasi belajar peserta didik (siswa). Jurnal Idaarah, I(2).

Nasbi, I. (2017). Manajemen kurikulum: Sebuah Kajian Teoritis. Jurnal Idaarah, $I(2)$.

Pebriantika, L. (2018). Pengembangan Bahan Ajar Berbasis Web Mata Pelajaran Biologi Kelas XI. Jurnal BAJET (Baturaja Journal of Educational Technology), 2(2).

Sugiyono.2019. Metode Penelitian Kuantitatif, Kualitatif dan $R \& D$. Bandung: Alfabeta.

Sukirman, D., \& Nugraha, A. (2016). Hakikat Kurikulum. In Kurikulum dan bahan belajar TK (PGTK2403/M). Jakarta: Universitas Terbuka. 